\title{
KEŞAN HERSEKZADE AHMET PAŞA CAMIII HAZİRESİNDE BULUNAN MEZAR TAŞLARI
}

\author{
Murat KARADEMIR* \\ İbrahim KUNT**
}

\begin{abstract}
ÖZ: Araştırmamızda Keşan Hersekzade Ahmet Paşa Camii haziresi içerisinde, günümüze sağlam olarak gelebilmiş 11 adet mezar yer almaktadır. Bu mezarlardan 1 tanesi sandık mezar (sembolik lahit) diğerleri toprak mezardır. Mezar taşlarının hepsinin fotoğrafları çekilmiş ve kitabeleri okunmuştur. Örneklerin hepsinin başlık tipleri, formları ve bezeme özellikleri ele alınarak Türk mezar taşı sanatı içerisindeki yerleri belirlenmeye çalışılmıştır. Çalışmada her bir mezar taşı ayrı ayrı ele alınmış ve taşlar üzerinde genel bir değerlendirme yapılmıştır. Hazirede yer alan bazı mezar taşlarının tarihleri zamanla taşlarda oluşmuş olan tahribattan dolayı okunamamış, bazı mezar taşlarında da tarih bölümüne yer verilmediği dönemleri tam olarak tespit edilememiştir. Fakat süsleme konularına ve süslemede kullanılan motiflerin özelliklerine göre genel olarak 18. yüzyıl sonu ve 19. yüzyıla benzer örneklere bakılarak tarafımızdan tarihlendirilmiştir. İncelemiş olduğumuz mezar taşlarından en erken tarihli örnek 1519 tarihine en geç tarihli örnek ise 19. yüzylla aittir. Taşlarda işleme yöntemi olarak zemin oyma tekniği uygulanmıştır. Sade örneklerin ön planda olduğu mezar taşlarında süsleme kompozisyonu açısından asma, kıvrık dallar, gül demetleri, selvi olmak üzere bitkisel karakterli motiflere yer verilmiştir. Geç dönem örneklerinde mimariye bağlı değişimin mezar taşlarında da kendini göstermesi sonucunda süsleme programında farklılıklar görülmektedir. Haziredeki mezar taşları sosyal ve kültürel açıdan Osmanlı mezar taşı geleneğini devam ettiren örnekler olarak dikkat çekmektedir.
\end{abstract}

Anahtar Kelimeler: Keşan, Hersekzade Ahmet Paşa Camii, Süsleme, Mezar Taşı

\section{THE GRAVESTONES WHICH IS LOCATED IN KESAN HERSEKZADE AHMET PASHA MOSQUE}

\begin{abstract}
In our research, there are 11 graves that have survived to the present day in the grave of Kesan Ahmet Pasha mosque. One of these tombs is coffer grave (symbolic sarcophagus), others are tombs, which are covered by soil (not by concrete or stone). All the gravestones were photographed and their epitaph were read. By examining the title types, forms and decoration
\end{abstract}

* Dr. Öğr. Üyesi, Selçuk Üniversitesi, Edebiyat Fakültesi, Sanat Tarihi Bölümü, mkarademir@selcuk.edu.tr ORCID: https://orcid.org/0000-0002-9776-3789

** Doç. Dr., Selçuk Üniversitesi, Edebiyat Fakültesi, Fars Dili ve Edebiyatı Bölümü, kuntibrahim@gmail.com ORCID: https://orcid.org/0000-0002-3419-6860

Geliş Tarihi (Received): 18.06.2019

Kabul Tarihi (Accepted): 25.10.2019

Yayın Tarihi / Published: 17.02.2020 
features of all the examples, we tried to determine their place in the Turkish tombstone art. In this study, each tombstone was examined separately and general evaluation was made on stones. The time of some gravestones in the grave is sought because of the destruction of the stones in time and some places in the gravestones are not included in history. However, it is dated by us while looking at examples of the termination date and similar examples from the 19th century. In the three tombstones, the years unknown, because the stones remained under the ground. The earliest specimen of the tombstones that we examined belongs to 1519 and the latest specimen belongs to the 19th century. In others, there were no dates. Ground carving technique was applied as a method of processing stones. The gravestones, where simple examples were at the forefront, were decorated with floral motifs including vine, curved branches, rose bouquets and cypresses. Late period examples show differences in tombstones due to the change in architecture and there are differences in ornamentation program. The tombstones stand out as examples that continue the Ottoman tombstone tradition in terms of social and cultural terms.

Keywords: Kesan, Hersekzade Ahmet Pasha Mosque, Decoration, Gravestone

\section{GíRIş}

Kökeni inançlara dayanan ve kültürel geleneği yansıtan mezar taşları, Türk tarihi ve sanatı açısından vazgeçilmez kültür varlıklarımızdandır. Türklerde mezar geleneği, Türk tarihinin başlangıcından itibaren bugüne kesintisiz bir şekilde devam etmiştir. Tarihin en eski dönemlerinden bu yana atalara duyulan büyük saygı dolayısıyla mezarlara önem verilmiş ve Türk sanatı tarihinde mezar yapıları ve mezar taşları önemli bir yer almıştır ${ }^{1}$. Mezar taşları bulundukları bölgenin demografik, ekonomik, sosyal ve kültürel yapısını yansıtmaları bakımından oldukça önemlidir. Bununla birlikte mezar taşları ölen kişi hakkında genel bilgiler içermekte, dönemin kılık-kıyafeti, aile yapısı, sosyal ve idari tarihi, sanat tarihi, dil ve edebiyat tarihi hakkında da önemli bilgiler vermektedir ${ }^{2}$.

Hersekzade Ahmet Paşa Camii, Edirne'nin en büyük ve en uzak ilçelerinden birisi olan Keşan ilçe merkezinde, Büyük Cami Mahallesinde, Hersekzade Ahmet Paşa Sokakta, 30 pafta, 383 ada ve 5 parselde yer almaktadır. Caminin günümüzde kitabesi bulunmadığı için inşa tarihi kesin olarak bilinmemektedir. Bununla birlikte Hersekzade Ahmet Paşa'nın H. 917/ M. 1511 tarihli vakfiyesinden yola çıkarak 16. yüzyılın ilk çeyreğinde inşa edilmiş olması kuvvetli ihtimaldir ${ }^{3}$.

$\mathrm{Bu}$ çalışmamızda Keşan Hersekzade Ahmet Paşa Camisi haziresinde günümüze ulaşan mezar taşları ayrıntılı olarak ele alınacaktır. Daha önce bu

\footnotetext{
${ }^{1}$ Sedat Veyis Örnek, 100 Soruda İlkelerde Din, Büyü, Sanat, Efsane, İstanbul, 1988, s. 93.

${ }^{2}$ H.P. Laqueur (Çev. Selahattin Dilidüzgün), Hüve'l- Baki Ístanbul'da Osmanlı Mezarlıkları ve Mezar Taşlarl, İstanbul, 1997, s. 168.

3 Murat Karademir, "Keşan'da Bir Osmanlı Hatırası: Hersekzade Ahmet Paşa Camii", Hersekzade Ahmet Paşa Cami Sempozyum Bildirileri ve Etkinlikleri 15 Nisan 2011, Edirne, 2012, s. 71-72. 
konu ile ilgili Hakan Akıncı'nın sunmuş olduğu bildiride haziredeki mezar taşlarının bir kısmı (7 adet mezar taşı) ele alınmış ancak mezar taşlarının toplu bir tipolojisi yapılmamış ve Osmanlı sanatı içerisindeki yeri belirlenmemiştir ${ }^{4}$. Yayında özgün metinler yazılmadığı gibi yazarın okumalarında hatalar dikkat çekmektedir. Akıncı'nin ele aldığı yayın Hersekzade Camii haziresindeki mezar taşlarından ziyade Kara Taşlı Mezarlıkları üzerinedir.

Keşan Hersekzade Ahmet Paşa Camii haziresi içerisinde, günümüze sağlam olarak gelebilmiş 11 adet mezar taşı yer almaktadır. Bu mezarlardan 1 tanesi sandık mezar (sembolik lahit) diğerleri toprak mezardır. Mezar taşları içinde dönem olarak en erken tarihli örnek Hersekzade Ahmet Paşa Camii'nin inşa tarihi olarak kabul edilen 16. yüzyıla aittir. Mezar taşları içinde en geç tarihli örnek ise 19. yüzyıla aittir.

Çalışmamız başta giriş olmak üzere katalog, değerlendirme ve sonuç olarak dört ana başlık altında toplanmıştır. Giriş bölümünde konu hakkında genel bilgiler verilmiştir. Katalogda her bir mezar taşı için ayrı ayrı gözlem fişleri oluşturulmuş, mezar yapıları üzerinde yer alan baş veya ayak taşlarının ayrıntılı tanımları bu gözlem fişleri içinde ele alınmıştır. Değerlendirme bölümünde ise katalogda detaylı incelenen mezar tipleri, mezar taşlarının tipleri, kullanılan başlıklar, süsleme ve sembolik anlam, malzeme ve işleniş ile taşlarda yer alan kitabe metinleri başlı̆g 1 adı altında genel bir değerlendirme yapılmıştır. Sonuç bölümünde ise çalışma kapsamında ulaşılan bilgiler verilmiştir.

Katalog No: 1

Fotoğraf No: $1-2-3$

Bulunduğu Yer: Edirne, Keşan Hersekzade Ahmet Paşa Camii Haziresi

Tarihi: H. 925/ M.1519

Kime Ait Olduğu: Perihan?

Formu/Biçimi: Baş ve ayak taşı düşey dikdörtgen prizma, açık lahit mezar tipi

Ölçüleri: Baş taş1: 81x33x6 cm

Ayak taş1: $150 \times 33 \times 12 \mathrm{~cm}$

\footnotetext{
${ }^{4}$ Yayımlanan bildiride kara taşlı mezarlıkların öneminden bahsedilmiş olup Edirne'deki mezarlıklardan örnek verilmiştir. Hersekzade Ahmet Paşa Camii haziresine de değinilmiş ayrıca cami içerisindeki kalem işlerine de yer verilmiştir. Ayrıntılı bilgi için Bkz. Hakan Akıncı, "Kara Taşlı Mezarlıkların Önemi ve Hersekzade Ahmet Paşa Camii Haziresinde Yer Alan Mezar Taşları”, Hersekzade Ahmet Paşa Cami Sempozyum Bildirileri ve Etkinlikleri 15 Nisan 2011, Edirne, 2012, s. 78-96. 


\section{Hattı: Celî Sülüs}

\section{Malzeme ve Teknik: Mermer, zemin oyma}

Tanım: Baş taşı; üstten yarısı kırılmış durumdadır. Bu nedenle kitabesi üç satırdan oluşmaktadır. Satırlar enine kalın silmeler ile birbirinden ayrılmıştır. Yazıda istif sanatı kullanılmıştır. Mezar taşının kenar bordürleri burmalı sütunçeler ile sınırlandırılmıştır.

Ayak taşı; sonradan konulmuş olup üslup olarak 18. yüzyıla tarihlenmektedir. Yukarıdan aşağı hafifçe daralan gövde ve tepelik bölümlerinden oluşmaktadır. Gövde bölümünün merkezinde selvi ağacı motifi yer almaktadır. Selvi ağacının etrafında asma ağacı motifi, asma yaprakları ve salkım üzümleri ile güzel bir kompozisyon yaratılmıştır. Tepe kısmında kenger yaprağı motifi görülmekte ve hemen onun alt kısmında ise vazodan çıkan gül, lale ve beş yapraklı çiçekler bulunmaktadır. Gövde ile tepelik arasında kalan alınlıkta bir bitkisel bordür kuşağı dikkati çekmektedir.

Lahit Mezar; dört cephesinde merkezde birer rozet yer almaktadır.

Kitabe metni: (Taşın üst kısmı kırık olduğundan tam olarak okunamamıştır. Sene satırının hemen üzerinde mâte yazıldığı görülmektedir. Mâte kelimesinin üzerinde Perihan kelimesine benzetilebilecek harfler vardır. Eğer vefat eden kişi bir hanım olsaydı, Arapça kurallara göre mâte yerine mâtet denilmeliydi. Dolayısıyla Perihan isminin de doğruluğu tartışmalıdır.)

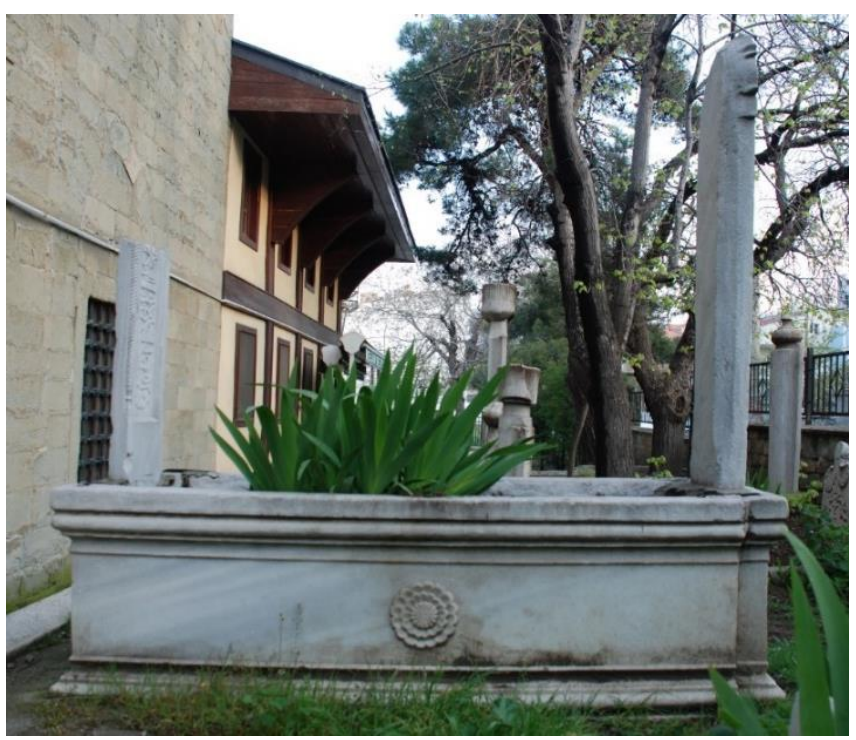

Fotoğraf No 1 


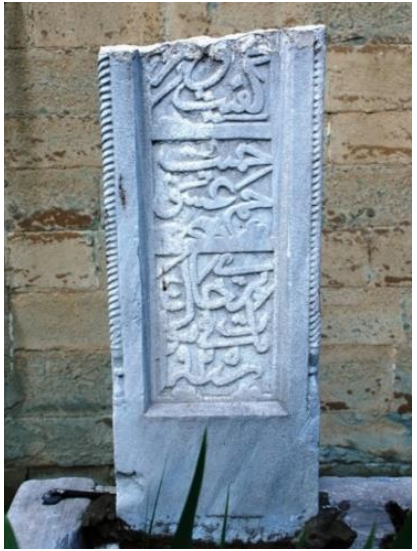

Fotoğraf No 2

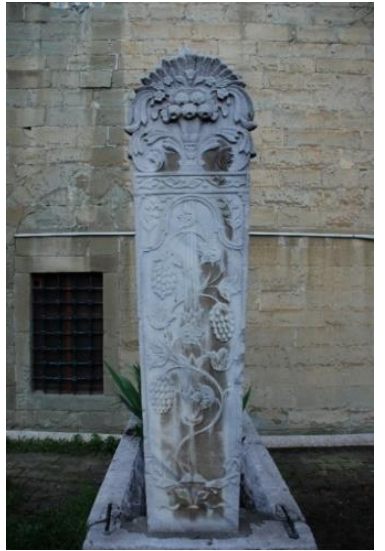

Fotoğraf No 3

Katalog No: 2

Fotoğraf No: 4

Bulunduğu Yer: Edirne, Keşan Hersekzâde Ahmet Paşa Camii Haziresi

Tarihi: 17. yüzy1l

Kime Ait Olduğu: $X$

Formu/Biçimi: Düşey dikdörtgen prizma

Ölçüleri: $105 \times 41 \times 7 \mathrm{~cm}$

Hattı: X

Malzeme ve Teknik: Taş, zemin oyma

Tanım: Düşey dikdörtgen mezar taşı, yukarıdan aşağ1 doğru daralmaktadır. Tepe kısmında büyük rozet bulunmaktadır. Bir silme ile taşta dikdörtgen bir alan görülmektedir. Bu alanın içerisinde Edirnekari olarak nitelendirilen kaş kemer ve kemerin iki yanında daha küçük ölçülerde birer rozet motifi görülmektedir ${ }^{5}$. Dilimli kemerin iç kısmının bazı yerlerinde dökülmeler mevcuttur. Bu alan boş bırakılmış herhangi bir yazı ya da süsleme öğesine rastlanmamaktadır.

\footnotetext{
5 Yapım tarihi bilinmeyen mezar taşı Edirnekâri şahide özelliği göstermekte ve benzer örneklerle karşılaştırıldığında 17. yüzyıla tarihlendirilmektedir. Edirnekâri şahideler için Bkz. Mehmet Kökrek, "Edirnekâri Şahideler”, Türk Dünyası Tarih Kültür Dergisi, C. 58, 2015, s. $18-21$. 


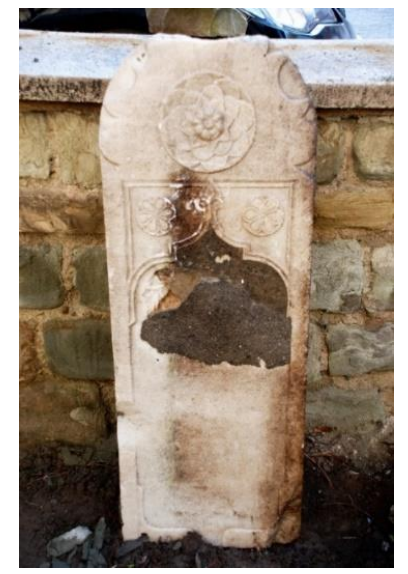

Fotoğraf No 4

Katalog No: 3

Fotoğraf No: 5

Bulunduğu Yer: Edirne, Keşan Hersekzade Ahmet Paşa Camii Haziresi

Tarihi: H. 1140 M./1727-28

Kime Ait Olduğu: Yazıcı Mustafa

Formu/Biçimi: Silindirik

Ölçüleri: $47 \mathrm{x} 22 \mathrm{~cm}$

Hattı: Celî Tâlik

Malzeme ve Teknik: Mermer, zemin oyma

Tanım: Silindirik formdaki mezar taşının üst kısmı kırılmış durumdadır. Enine silmeler ile üç satıra ayrılmıştır. Kırılan kısmın altında kalın bir silme, taşın etrafını sarmaktadır. Mezar taşında süsleme öğesi bulunmamaktadır.

Kitabe Metni:

\begin{tabular}{|l|r|}
\hline 6 & 6 \\
Merhûm Yazıcı Mustafa & مرحوم يازيجى مصطفى \\
Efendi rûhiçün & 1140 روحيجون 1140 \\
Sene 110 & 1 (فندى \\
\hline
\end{tabular}




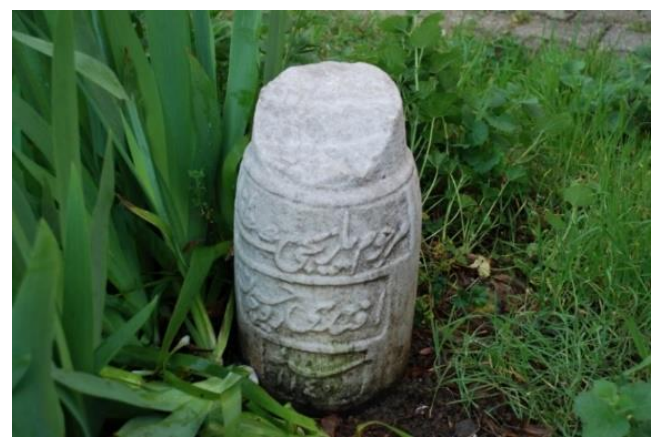

Fotoğraf No 5

Katalog No: 4

Fotoğraf No: 6

Bulunduğu Yer: Edirne, Keşan Hersekzade Ahmet Paşa Camii Haziresi

Tarihi: 18. yüzyl1 ${ }^{6}$

Kime Ait Olduğu: $X$

Formu/Biçimi: Düşey dikdörtgen prizma, Örfi destarlı sarık

Ölçüleri: $88 \times 32 \times 13 \mathrm{~cm}$

Hattı: Celî Sülüs

Malzeme ve Teknik: Mermer, zemin oyma

Tanım: Düşey dikdörtgen formlu gövde, boyunluk ve örfi destarlı kavuktan oluşmaktadır. Kitabe enine silmeler ile serlevha dahil sekiz satıra ayrılmıştır. Son satırın yarısı toprağın altında kalmıştır. Gövde bölümünün sol üst köşesi kırılmıştır. Metinde istif sanatı kullanılmıştır. Kitabede tirfil ve kesme işaretleri kullanılarak harf aralarındaki boşluklar doldurulmuştur. Başlık bölümü geleneksel tarzdaki bir kavuk türüdür. Bu sarık çeşidinde sarma biçimine ve büyüklüğüne göre makamlar değişmektedir? ${ }^{7}$

\footnotetext{
${ }^{6} \mathrm{Bu}$ başlık tipi, Emine Baş'ın yüksek lisans tezinden yola çıkılarak, Beylerbeyi Camii haziresinde yer alan mezar taşları ile karşılaştırılmış, üslup ve dönem karakteristiği olarak 18 . yüzyıla tarihlendirilmiştir. Ayrıntılı bilgi için Bkz. Emine Baş, Edirne Beylerbeyi Camii Haziresi'nde Bulunan Mezar Taşlarl, Edirne, Trakya Üniversitesi, Sosyal Bilimler Üniversitesi, Yayımlanmamış Yüksek Lisans Tezi, 2009, s. 553.

${ }^{7}$ Fatih Çavuş, Osmanlı Mezar Taşlarının Sırları, İstanbul, 2018, s. 122.

Trakya Üniversitesi Edebiyat Fakültesi Dergisi, Cilt: 10 Sayl: 19, Ocak 2020, s. 147-168
} 


\section{Kitabe Metni:}

\begin{tabular}{|c|c|}
\hline $\begin{array}{l}\text { Hüve'l-bâkî } \\
\text { Ah ah ey felek ah her zaman } \\
\text { Gitti oğlum ah Şerifim el-aman } \\
\text { Nâib idi bu kazâda ol velîd } \\
\text { Ravza idi bana hayât şimdi mihnet-keşân } \\
\text { Mâderin duhterlerin hasretle koydun ey } \\
\text { Şerif } \\
\text { Hasretinle tâ be-mahşer ederim âh u figân } \\
\text { Son satır okunamıyor }\end{array}$ & 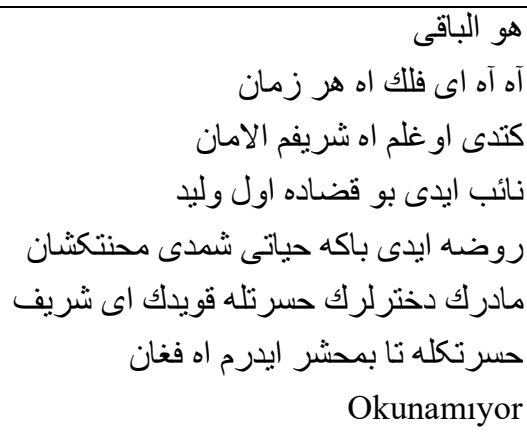 \\
\hline
\end{tabular}

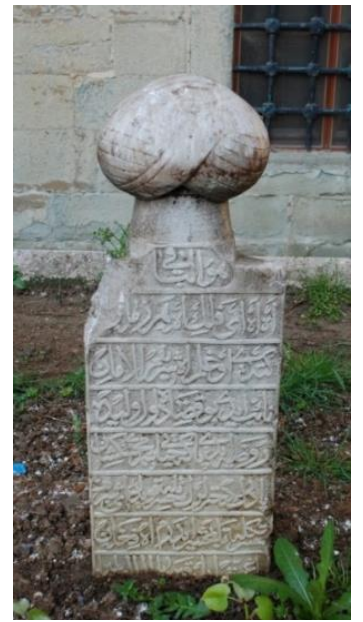

Fotoğraf No 6

\section{Katalog No: 5}

Fotoğraf No: 7

Bulunduğu Yer: Edirne, Keşan Hersekzâde Ahmet Paşa Camii Haziresi

Tarihi: 18 . yüzy1 ${ }^{8}$

Kime Ait Olduğu: $X$

\footnotetext{
8 18. yüzyıl mimari ve mimariye bağlı süslemede olduğu gibi mezar taşlarında da değişimin ayak izlerinin hissedildiği dönemdir. Mezar taşı barok-rokoko karakterli bitkisel tepelikli form göstermesinden dolayı üslup ve dönem özellikleri açısından 18. yüzyıla tarihlendirilmiştir. Bkz. Gülay Kurtişoğlu, "Sadelikten Gösterişe Edirne Osmanlı Dönemi Mezar Taşları", Trakya Üniversitesi Edebiyat Fakültesi Dergisi, Cilt:8, Sayı:16, Edirne, s. 34. 
Formu/Biçimi: Düşey dikdörtgen prizma

Ölçüleri: $147 \times 30 \times 9 \mathrm{~cm}$

Hattı: X

Malzeme ve Teknik: Taş, zemin oyma

Tanım: Düşey dikdörtgen, yukardan aşağı doğru daralan formdaki mezar taşının gövde bölümü boş bırakılmıştır. Mezar taşının tepelik kısmı iki yandan kıvrımlı kenger yaprakları ile sonlanmaktadır. Kenar hatlarında kalın silmeler görülmektedir.

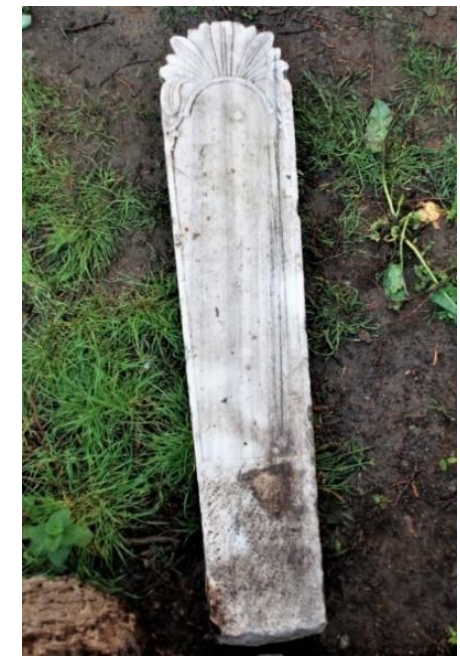

Fotoğraf No 7

Katalog No: 6

Fotoğraf No: 8

Bulunduğu Yer: Edirne, Keşan Hersekzade Ahmet Paşa Camii Haziresi

Tarihi: H.1227/ M. 1812-13

Kime Ait Olduğu: Kocaelili Mustafa Ağa

Formu/Biçimi: Düşey dikdörtgen prizma, Kâtibi kavuk

Ölçüleri: 180x45x19 cm

Hattı: Talik

Malzeme ve Teknik: Mermer, zemin oyma

Tanım: Düşey dikdörtgen biçimli gövdenin üzerinde yükselen, ön cephesi pahlanmış uzun bir boyun üzerinde kâtibi kavuk görülmektedir. Dikey şeritli 
kavuğun üzerine sarılan sarık yanlara doğru fazladan şişirilmeden, başlığın neredeyse yarısına kadar sarılmıştır. Gövde bölümü enine silmeler ile serlevha ve tarih bölümü dahil on altı satıra ayrılmıştır.

Kitabe Metni: Osmanlı Türkçesiyle yazılan manzum metin, aruzun remel bahrinin fâilâtün/fâilâtün/fâilâtün/fâilün vezniyle, yedi beyit halinde Zekî mahlaslı bir şair tarafından yazılmıştır. Manzumenin son mısraında tarih düşürme sanatı yapılmış, Kocaelili Mustafa Ağanın ölümüne tarih düşürülmüştür. Son satırın kelimelerini ebced hesabıyla topladığımızda 1226 sayıs1 elde edilmektedir. Olması gereken tarih ile manzumede söylenen tarih arasında bir fark bulunmaktadır. "Söyledim bir mısra' ile" lafzını "Söyledim bir fark ile" şeklinde anlamak gerektiği düşünülmektedir. Bu tarih, manzumenin bitiminde rakamla da kaydedilmiştir. Merhûmun ölüm tarihinin gün ve ayı da 25 Rebîülâhir olarak belirlenmiş, Rebiülâhir kelimesi metinde uzun uzun yazılmak yerine sadece "Ra" harfiyle gösterilmiştir. Bu tarih, miladi olarak 8 Mayıs 1812 tarihine tekabül etmektedir.

\begin{tabular}{|c|c|}
\hline Hüve'l-hallâku'l-bâkî & هو الخلاق الباقى \\
\hline Kocaelili Mustafa Ağa o zât-1 mecîd & قوجه ايليلى مصطفى آغا او ذات مجيد \\
\hline Hem silahşör-i şehinşâh-i cihân zıll-i Hudâ & هم سلحشور شهنشاه جهان ظل خدا \\
\hline Ömrün ifnâ eyleyip bezl ü cûd ile hemân & عمرن افنا ايليوب بذل و جود ايله همان \\
\hline Hayli müddet urdu dîn ü devlet içre püşt ü pâ & خيلى مدت اوردى دين و دولت ايجره هِت و پِا \\
\hline Pâdişâh-1 âleme sıdk ile hidmet ederek & يادشاه عالمه صدق ايله خدمت ايدرك \\
\hline Oldu fâni dehr içinde âkıbet pîr-i dü tâ & اولاى فانى دهر ايجنده عاقبت يِير دو تا \\
\hline Biri ez cümle Keşân'a Voyvoda olmuş iken & بيرى از جمله كثانه ويوه ده اولمش ايكن \\
\hline Etmeden hayfâ ikâmet eylemiş azm-i bekâ & ايتمدن حيفا اقامت ايلمش عزم بقا \\
\hline Koyup İslambol'da Seyyid Mir Ali ferzendini & قويوب اسلامبولده سيد مير على فرزندنى \\
\hline İhtiyâr etti diyâr-1 gurbeti vâ hasretâ & اختيار ايتدى ديار غربتى وا حسرتا \\
\hline Hâsılı kabrin ziyâret eyleyen ihvân-1 dîn & حاصلى قبرن زيارت ايلين اخوان دين \\
\hline Okuyup bir fâtiha hem rûhuna kilsın duâ & اوقويوب بر فاتحه هم روحنه قلسون دعا \\
\hline Söyledim bir misra' ile bende târîhin Zekî & سويلدم بر مصر ع ايله بنده تاريخن زكى \\
\hline Kasr-1 Firdevs-i cinân oldu mekân-1 Mustafa & قصر فردوس جنان اولدى مكان مصطفا \\
\hline Sene 1227 & سنه 1227 \\
\hline Fî 25 Rebîülâhir & فى 25 ر \\
\hline
\end{tabular}




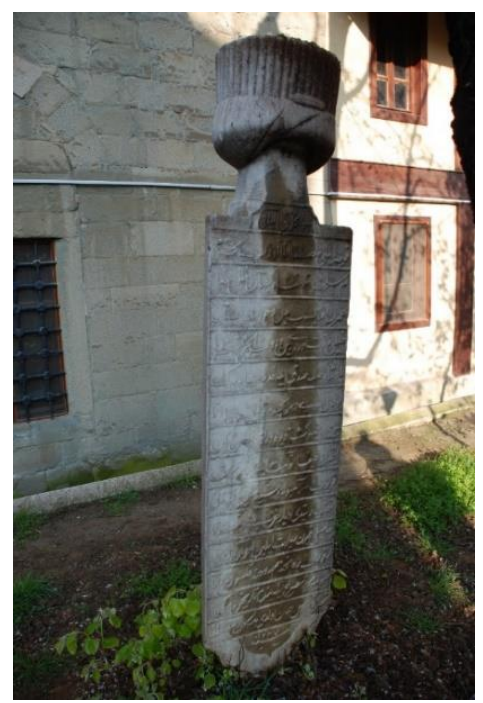

Fotoğraf No 8

Katalog No: 7

Fotoğraf No: 9

Bulunduğu Yer: Edirne, Keşan Hersekzâde Ahmet Paşa Camii Haziresi

Tarihi: 19. yüzyılın ilk yarısı9.

Kime Ait Olduğu: $\mathrm{X}$

Formu/Biçimi: Kâtibi Kavuk

Ölçüleri: $21 \times 17 \mathrm{~cm}$

Hattı: X

Malzeme ve Teknik: Mermer, zemin oyma

Tanım: Kâtibi kavukta ince dikey dikişli kavuğun üzerindeki sarık, kavuğu bütünüyle sararken üst bölümde dar bir şerit sarılmadan bırakılmıştır.

\footnotetext{
${ }^{9}$ Kâtibi kavuk 1828 de II. Mahmut zamanında çıkarılan kıyafet nizamnamesinden önce mevki ve ünvanları ne olursa olsun memurların giydikleri kavuk çeşididir. Bkz. Mustafa Sürün, "İstanbul Şeyh Vefa Camii Haziresi Mezar Taşları Tipolojisi Üstüne Bir Değerlendirme", Marmara Üniversitesi Türkiyat Araştırmaları Enstitüsü Türk Sanatı Anabilim Dalı Türk Sanatları Bilim Dalı (Yayınlanmamış Yüksek Lisans Tezi), İstanbul, 2006. İstanbul hazirelerinde çokça görülen bu başlık tipi Şeyh Vefa Camii Haziresindeki örneklerle kıyaslanarak 18. yüzyıla tarihlendirilmiştir. 


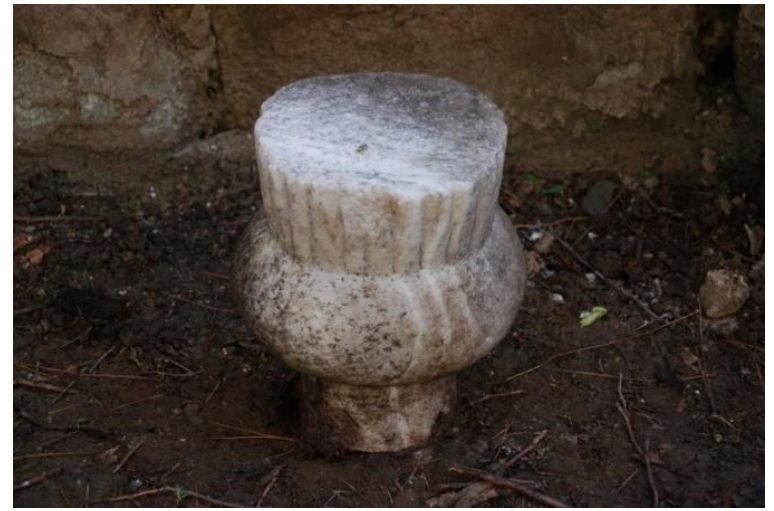

Fotoğraf No 9

\section{Katalog No: 8}

Fotoğraf No: 10

Bulunduğu Yer: Edirne, Keşan Hersekzade Ahmet Paşa Camii Haziresi

Tarihi: Mezar taşı, başlığına göre 19. yüzyıl ortalarına tarihlenmektedir.

Kime Ait Olduğu: Mîr İbrahîm

Formu/Biçimi: Düşey dikdörtgen prizma, Mahmudi Fes başlık

Ölçüleri: 107x34x15 cm

\section{Hattı: Celî Sülüs}

Malzeme ve Teknik: Mermer, zemin oyma

Tanım: Düşey dikdörtgen prizma formlu gövde, köşeleri pahlı, kademeli boyunluk ve Mahmudi Fes başlıktan oluşmaktadır. Kitabe bölümü enine ince silmeler ile yedi satıra ayrılmıştır. Serlevha geometrik bir kartuş içinde ayrı bir şekilde verilmiştir. Gövdenin üst alınlığında stilize kıvrık dallar ve gül motifi görülmektedir. II. Mahmud dönemine ait fes başlık olarak kullanılmış olup bu fes dönem özelliğidir. 1808-1839 yıllarında çokça kullanılmıştır. Mahmudi feslerin altı dar olup üst tarafı daha geniştir ve püsküllü olarak kullanılır. Bu mezar taşı başlığında aynı özellikleri görmekteyiz. 


\section{Kitabe Metni:}

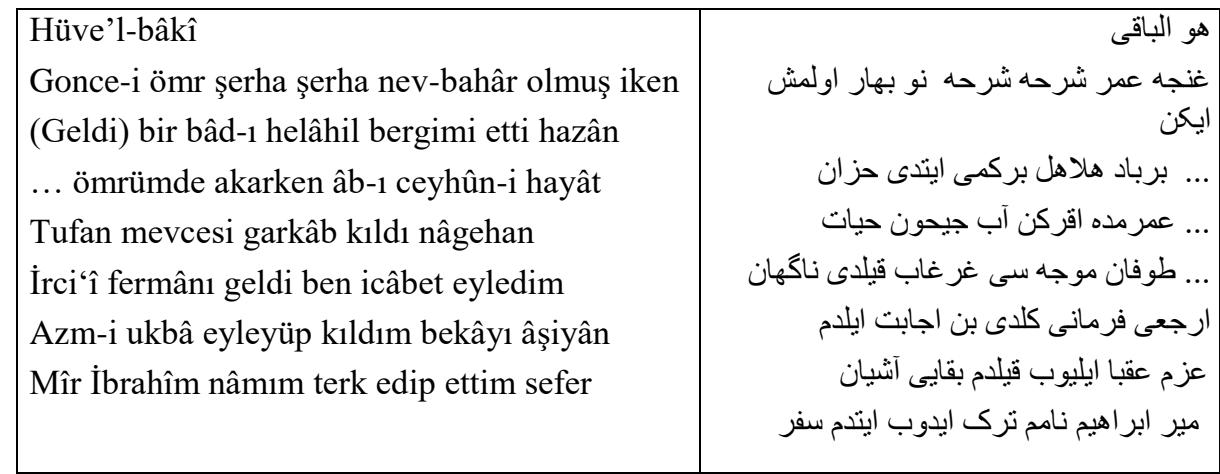

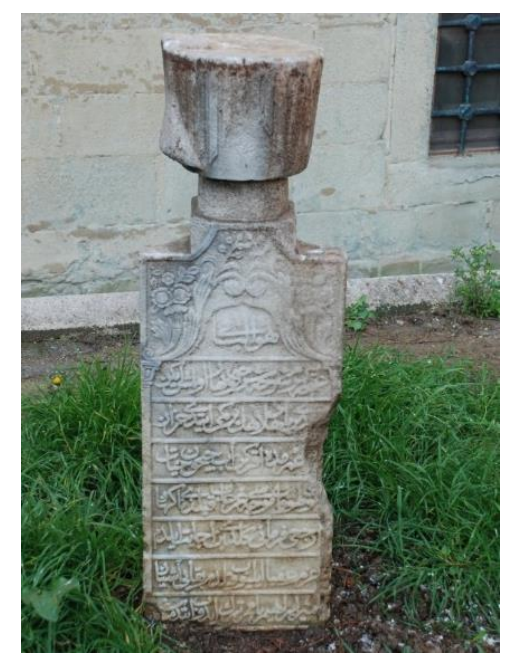

Fotoğraf No 10

Katalog No: 9

Fotoğraf No: 11

Bulunduğu Yer: Edirne, Keşan Hersekzade Ahmet Paşa Camii Haziresi

Tarihi: 19. yüzy11 ${ }^{10}$

Kime Ait Olduğu: X

\footnotetext{
${ }^{10}$ 19. yüzyıl mezar taşlarında yukarıdan aşağıya doğru daralan dikdörtgen formlu tip süsleme programı olarak tamamen Avrupa'dan gelen sanat akımlarının etkisindedir. Kemer alınlıklarında vazoda çiçek ve meyveler, stilize edilmiş yapraklar görülmektedir. G. Kurtişoğlu, agm., s. 42. 
Formu/Biçimi: Düşey dikdörtgen prizma, başlıksız

Ölçüleri: $75 \times 46 \times 11 \mathrm{~cm}$

Hattı: Talik

Malzeme ve Teknik: Mermer, zemin oyma

Tanım: Düşey dikdörtgen formlu mezar taşının yarısının toprağın altında kaldığ 1 görülmektedir. Enine silmeler ile birbirinden ayrılmış üç satır ve başlık formuna benzer bir kartuşun içerisinde serlevha kısmı görülmektedir. Mezar taşının üst alınlığında merkezde tabak içerisinde meyvelere (kayısı) yer verilmiştir. Etrafında ise stilize bitkisel süslemelere ve palmetlere yer verilmiştir. Mezar taşının tepelik kısmı madalyondan oluşmaktadır. Boyunluk bölümünün iki kenarında yana doğru kıvrılan girland motifi izlenmektedir.

Kitabe Metni:

\begin{tabular}{|c|c|}
\hline 5 & 5 \\
\hline Fâtiha & فاتحه \\
\hline Medîne-i Keşân nâibi müderrisîn-i kirâm & مدينهُ كثان نائبى مدرسين كرام \\
\hline Zevi'l-ihtirâmdan fazîletlû Ahmed Rüşdi & ذوى الاحتر امدن فضيلتلو احمد رشدى \\
\hline .. & \\
\hline
\end{tabular}

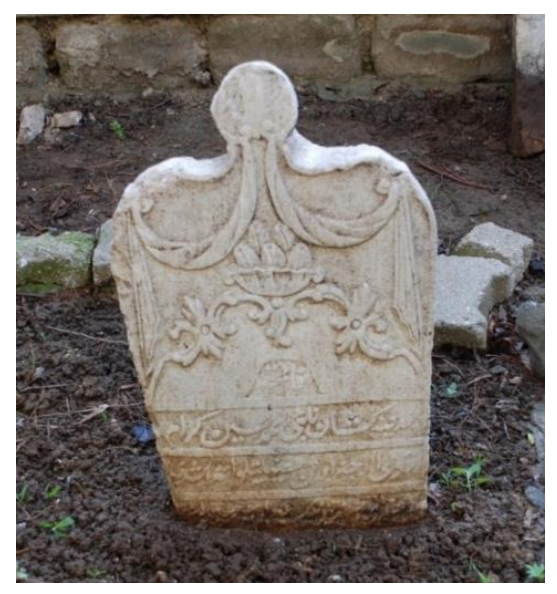

Fotoğraf No 11

Katalog No: 10

Fotoğraf No: 12

Bulunduğu Yer: Edirne, Keşan Hersekzâde Ahmet Paşa Camii Haziresi

Tarihi: 19. yüzy1l. 


\section{Kime Ait Olduğu: $X$}

Formu/Biçimi: Düşey dikdörtgen prizma

Ölçüleri: 105 x 32 x11 cm

\section{Hattı: X}

Malzeme ve Teknik: Mermer, zemin oyma

Tanım: Gövde kısmı ve hotoz başlığa benzer bir başlık kısmından oluşmaktadır. Gövde yukarıdan aşağı doğru daralmaktadır. Gövde merkezinde bulunan vazodan çıkmış bir Selvi ağacı ve çevresinde asma ağacı, salkım üzümler görülmektedir. Mezar taşı üst alınlığında kenger yaprağından oluşan bir kompozisyon vardır. Başlıktaki hotoza bakıldığında bir kadına ait ayak taşı olduğu anlaşılmaktadır.

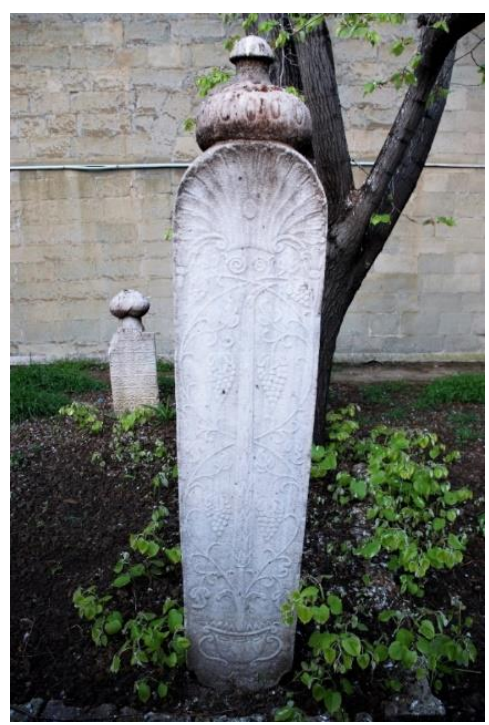

Fotoğraf No 12

Katalog No: 11

Fotoğraf No: 13

Bulunduğu Yer: Edirne, Keşan Hersekzâde Ahmet Paşa Camii Haziresi

Tarihi: 19. yüzy1l

Kime Ait Olduğu: $X$

Formu/Biçimi: Düşey dikdörtgen prizma

Ölçüleri: $66 \times 33 \times 8 \mathrm{~cm}$

Hattı: X 
Malzeme ve Teknik: Mermer, zemin oyma

Tanım: Düşey dikdörtgen ayak taşı, yukarıdan aşağı doğru daralmaktadır. Normalde sivri kemer olan taşın üst kısmı kırılmıştır. Taşın alt kısmı da tahrip olmuştur. Ayak taşının merkezinde hurma ağacı görülmektedir. Hurma ağacı motifi cennet meyvesidir. Ayrıca hac vazifesini yapan hacıların ayak taşlarına işlenmektedir ${ }^{11}$.

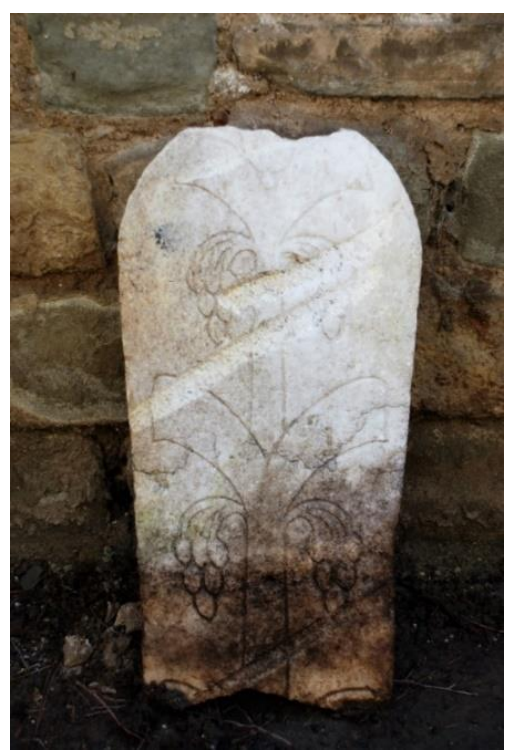

Fotoğraf No 13

\section{DEĞERLENDİRME}

Mezar taşları ile ilgili olarak çeşitli tipoloji araştırmaları yapılmıştır. Bu araştırmalar günümüze 1şık tutarak mezar taşlarının nasıl ele alınması gerektiği konusunda bize yön vermiştir. Osmanlı mezar taşlarının, İstanbul ağırlıklı olmak üzere Trakya ve Anadolu'dan 1200 örneğe dayalı sınıflaması Bacque-Grammont/Vatin/Laqueur (1990) tarafından yapılmıştır ${ }^{12}$.

Osmanlı Devleti'nin en önemli merkezlerinden birisi olan ve aynı zamanda başkentlik yapmış bir şehir olan Edirne, imar edilmiş semtleriyle gelişmiş bir şehre dönüşerek, bünyesinde barındırdığı şaheserlerle Osmanlı tarihindeki yerini almıştır. Bilindiği üzere kentleri kent yapan en önemli unsurlardan bir

${ }^{11}$ F. Çavuş, age., s. 67.

12 J.L. Bacque, vd., "Tarihsel Kaynak Olarak Osmanlı Mezarlıkları: Uygulanan Yöntemler ve Bilgisayarda Yapılabilecek İşlemler”, Erdem, Ocak-1990, Cilt: 6, Sayı: 16, 1992, s. 197. 
tanesi de o kentin görsel kimliğini oluşturan anıtsal mimarisidir. Bu anıtsal mimarinin içinde camiler ve mescitler ayrı bir yer tutmaktadır. Bu bağlamda Edirne, 14. yüzyılın sonlarından itibaren başta cami ve mescitler olmak üzere yoğun imar faaliyetlerine sahne olmuştur. Türk sanatının bu anıtsal yapılarının yanında yine Türk sanatının en küçük yapıtları olan ve yaşanmış hayatların ve sosyo-kültürel olayların bir vesikası olan mezar taşları Edirne kent tarihi açısından bir bütünlük oluşturmaktadır. Bu durum Edirne ve çevresindeki yerleşim yerleri içinde geçerlidir.

Edirne'deki Osmanlı Dönemi mezar taşları formları, kitabeleri ve süslemeleriyle önemli bir yere sahiptir ${ }^{13}$. Edirne'deki mezar taşları tiplerinin daha sade olmakla birlikte benzer örnekleri Keşan ilçesindeki Hersekzade Ahmet Paşa Camii haziresinde yer almaktadır.

\section{Mezar Tipleri}

Osmanlı dönemini kapsayan mezar tipolojisi araştırmalarında mezar tipleri genel olarak beş bölümde incelenmiştir. Bunlar; Toprak mezarlar, Çerçeveli mezarlar, Kapak taşlı mezarlar, Sandukalı mezarlar ve Sandık (lahit) mezarlar olarak tipolojik açıdan sınıflandırılmıştır ${ }^{14}$. Bu beş bölümde kendi içlerinde alt başlıklara ayrılmaktadır.

Keşan Hersekzade Ahmet Paşa haziresindeki mezar tipleri biri sandık (lahit) mezar olmak üzere diğerleri toprak mezarlar tipolojisine girmektedir. $\mathrm{Bu}$ araştırmada iki mezar tipi incelenmiştir.

\section{Mezar Taşı Tipleri}

Halit Çal tarafindan geliştirilen tipolojiyi örnek alarak bu çalışmada sınıflandırmaya gidilmiştir ${ }^{15}$. Halit Çal'ın tipolojisine göre mezar taşları kadın ve erkek taşları şeklinde değil, mezar taşı gövde kesitinin dikdörtgen, kare, çokgen ve yuvarlak oluşuna, mezar taşının ön görünüşüne, başlıklı olup olmamasına göre tasnif edilmiştir ${ }^{16}$.

Keşan Hersekzade Ahmet Paşa haziresindeki mezar taşlarında görülen tipolojide düşey dikdörtgen gövdeli başlıklı ya da tepelikli tip görülmektedir. Kat. No. 2'de görülen Edirnekari mezar taşı üzerinde tarih ibaresi bulunmamakla birlikte N. İşli'nin makalesinden yola çıkılarak 17. yüzyıla

\footnotetext{
${ }^{13}$ G. Kurtişoğlu, agm, s. 34.

${ }^{14}$ Halit Çal, "Türklerde Mezar-Mezar Taşları", Aile Yazıları, Sayı:8, Ankara, 2015, s. 303-305

${ }^{15}$ Halit Çal'ın yapmış olduğu yayınlardan bazıları şunlardır: Halit Çal., "Türklerde MezarMezar Taşları", Aile Yazıları, S. 8, 2015, Ankara, s. 303-305. Halit Çal., "İstanbul Eyüp’teki Erkek Mezar Taşlarında Başlıklar”, Tarihi, Kültürü ve Sanatıyla Eyüp Sultan Sempozyumu III. Tebliğler, 1999, İstanbul s, 206-217; Halit Çal- Özlem Ataoğuz Çal, Kastamonu Atabey Gazi Camisi ve Türbesi Haziresindeki Mezar Taşları, Ankara, 2008.

${ }^{16}$ H. Çal,- Ö. A. Çal, age., s. 358.

Trakya Üniversitesi Edebiyat Fakültesi Dergisi, Cilt: 10 Sayl: 19, Ocak 2020, s. 147-168
} 
tarihlendirilmiştir. Edirnekari üslubu Edirne'de ortaya çıkmasından dolayı bu isimle adlandırılmıştır ${ }^{17}$. Yalnızca bir daire kesitli tipte baş taşı görülmektedir. Araştırılan mezar taşlarında altı tane baş taşı, beş tane ayak taşı ve bir adet başlık bulunmaktadır.

Edirne'deki mezar taşları tip olarak incelendiğinde Hersekzade Camii haziresindeki mezar taşlarında görülen düşey dikdörtgen gövdeli başlıklı, Edirnekari ve tepelikli tip dışında mihrabiyeli mezar taşları, Zeyni mezar taşları ve Üsküflü mezar taşları da yer almaktadır ${ }^{18}$.

\section{Başlık Tipleri}

Başlık, çeşitli amaçlarla başa giyilen nesnelere verilen genel bir isimdir. Osmanlı döneminde baş giyimleri, dönemlerine göre pek çok şekil almıştır ${ }^{19}$. Mezar taşlarının başlıkları yatan kişinin mesleği, sosyal ve ekonomik durumu, tarikatı, ailesi ve pek çok konuda bilgi vermektedir. Halit Çal'ın yaptığ tipolojiye bağlı kalarak sarık, kavuk, fes tarikat başlıkları olarak ayrılmaktadır. Dönemin günlük yaşantısında görülen başlıklar mezar taşı başlığı olarak kullanılmıştır.

Edirne'deki mezar taşlarında en fazla görülen tip başlıklı mezar taşlarıdır. Muradiye ve Üç Şerefeli Camii haziresinde de başlıklı tipin daha yoğun olarak kullanıldığ görülmektedir. Keşan Hersekzade Ahmet Paşa haziresindeki mezar taşlarında kullanılan başlık tipleri iki kâtibi kavuk başlık (Kat. No: 67), bir Örfi destarlı sarık başlık (Kat. No: 4) ve Mahmudi fes (Kat. No: 8) başlık şeklindedir. Kâtibi kavuk türü dikişleri ve sarıkların sarılış biçimine göre birbirinden ayrılmaktadır. Bilinen dokuz çeşidi vardır. Bazı çeşitleri, kapı kethüdaları, kâtipler, kapıkulları, saray görevlileri, orta dereceli memurlar, esnaf grupları ve alt kademe din adamları tarafından giyilirdi. Mezarlıklarda en çok rastlanan başlık türüdür. Yaygın olarak XVII. yüzyılı başı ile XIX. yüzyılın ortaları arasında kullanılmıştır ${ }^{20}$. Örfi destarlı sarık küçük dereceli ulema, küçük ve orta dereceden kadılar, imamlar ve vakıflarda çalışanlar takmaktadır. $\mathrm{Bu}$ sarık çeşidinde sarma biçimine ve büyüklüğüne göre makamlar değişmektedir ${ }^{21}$. Mahmudi fes başlık II. Mahmud döneminde kullanılan feslere denmektedir. Bu feslerin altı dar üstü geniştir. Birden fazla

${ }^{17}$ N.H. İşli, “Edirne Mezarları ve Taşları”, Edirne: Serhattaki Payitaht, İstanbul, 1998, s. 445 447.

18 Mustafa Özer, "Edirne'deki Osmanlı Dönemi Mezarlıkları-Hazireler, Mezar Taşları ve Türbeler", Konya Kitabı X (Rüçhan Arık - M. Oluş Arık'a Armağan), Konya, 2007, s. 507-524.

${ }^{19}$ Celal Esat Arseven, "Baş Giyimi - Baş Giyeceğii”, Sanat Ansiklopedisi, C. I, 1983, s.184.

${ }^{20}$ Mahmut Ökçesiz, Kuşadası Adalızade Osmanlı Mezar Taşları, İstanbul, 2013, s. 19

${ }^{21}$ F. Çavuş, age.,s. 171. 
püskül görülebilmektedir. Mezar taşlarında yaygın kullanıldığı bilinmektedir ${ }^{22}$.

\section{Süsleme ve Sembolik Anlam}

Mezar taşlarında süsleme baş taşlarında başlık ve alınlıklarda daha çok görülmektedir. Ayak taşlarında ise alınlık ve gövde kısmında yoğunlaştığı görülmektedir. İncelemiş olduğumuz mezar taşlarında ağırlıklı olarak bitkisel karakterli motifler yer almaktadır. Bitkisel motifler ise, Selvi ağacı, asma ağacı, hurma ağacı, lale, gül, yapraklı çiçekler, kıvrık dallar, girland, stilize bitkisel şua ve madalyon motifleri ve meyve tasvirleri şeklindedir. Ayrıca nesneli süsleme öğesi vazo ve tabak tasvirleri de görülmektedir. $\mathrm{Bu}$ süslemelerin hepsinin bir yapılış amacı ve sağladığı bir sembolik anlam bulunmaktadır. Selvi ağacı tasavvufta da önemli yer tutmaktadır. Allah yazılışının ilk harfi Elifi simgeler ve Vahdet-i vücudun bir işareti olarak kabul edilmektedir ${ }^{23}$. Selvi ağacı incelediğimiz Katalog No 1 ve 7 de görüldüğü gibi asma dalları ve üzüm salkımları ve lale motifi ile beraber kullanıldığı görülmektedir. Asma ağacı, asma yaprakları ve salkım üzümler ile birlikte tasvir edilmiştir. Asma ağacının kullanılması üzümün cennet meyvesi olması kullanımında yaygındır. Asma ağacının mezar taşlarında kullanımı bütün bir yüzeyi kaplayacak şekilde ya da Selvi ağacının etrafında görebilmekteyiz ${ }^{24}$. Hurma ağac1, Katalog No 11 'de görülmektedir. Hurma ağac1 cennet meyvesidir ve hac ibadetini hatırlatmaktadır. Mezar taşlarında hurma ağacı motifinin olması o kişinin hacı olduğunu anlatmaktadır ${ }^{25}$. Gazi Mihal Camii ve Beylerbeyi Camii haziresinde de hurma ağacı motifi yaprak ve salkımları ile birlikte tasvir edilmiştir ${ }^{26}$. Lale motifi Katalog No 1'de görülmektedir. Lale Allah'1 temsil eder; yani vahdet-i vücudun bir işaretidir. Bu motifte aynı Selvi gibi Elif harfine benzetilmektedir. Bu önemi itibari ile de lale motifi mezar taşlarında görülmektedir. Mezar taşlarında gül motifi sıkça karşımıza çıkmaktadır. Katalog No 1 ve 8' de görülmektedir. İslam sanatında gül Hz. Muhammed'in sembolü olarak kabul edilmektedir ${ }^{27}$. Kıvrık dal geç Osmanlı mimarisinde çokça kullanılmış bir süsleme öğesidir. Mimariden diğer süsleme alanlarına da aktarılmıştır. Bunlardan biri de mezar taşlarıdır. Kıvrık dal motifleri Katalog No 1,8,9 ve 10 da örnekleri görülmektedir. Girland motifi Katalog No 9'da madalyon tepeliğin altında bulunmaktadır. Meyve tasvirleri, ölümsüzlük sembolüdür. Kuran-1 Kerim'de geçen meyveler genelde mezar

\footnotetext{
${ }^{22}$ H.P. Laqueur, age.,s. 147.

23 İskender Pala, Divan Şiiri Sözlüğ̈̈, İstanbul, 1999, s. 350.

${ }^{24} \mathrm{~F}$. Çavuş, age., s. 171.

${ }_{25}$ Ömer Faruk Dere, Eyüp Sultan'da Taşa İşlenen Medeniyet, İstanbul, 2011, s. 99.

${ }^{26}$ E. Baş, agt, s. 559.

${ }^{27}$ Beşir Ayvazoğlu, Güller Kitabı, İstanbul, 1999, s. 95. 
taşlarında süsleme öğesi olarak kullanılmıştır. Genelde meyveler bir tabağın içinde tasvir edilmiştir ${ }^{28}$. Meyve tasvirî Katalog No 9'da görülmektedir. Kenger yaprağı incelenen örneklerde ayak taşlarının alınlığında kullanılmıştır. Geç dönemde yaygın bir şekilde kullanılan bu motif Katalog No 1, 4 ve 10'da görülmektedir.

\section{Malzeme ve İşleniş}

İnceleme konumuzu oluşturan mezar taşlarında, yörede sık olarak bulunan değişik yapıdaki taşlar görülmektedir. Bu taşlardan bazıları ilk bakışta mermer hissi vermekte, ancak detaylı bir biçimde incelendiğinde mermer olmadığı tespit edilebilmektedir. Mermer malzeme kullanılan mezar taşları da bulunmaktadır. $\mathrm{Bu}$ malzeme ölen kişinin ekonomik durumuna göre değişmekte olup bazı mezar taşlarında kaba, koyu renk mermer kullanımı görülmektedir. Edirne'deki erken tarihli mezar taşı örneklerinde ise kalker ve küfeki taşının kullanıldığı görülmektedir ${ }^{29}$. Mezar taşlarında, işleme yöntemi olarak ise, zemin oyma tekniği kullanılmıştır. Bu teknikte yazı ve desenler yüzeye çizildikten sonra etrafları aletler yardımıyla oyulmuş, kenarları ise çerçeve oluşturacak biçimde boş bırakılmıştır.

\section{Kitabe Metni}

Mezar taşları, üzerlerinde yer alan kitabeleri ile de dikkat çekmektedir. İncelenen mezar taşlarında sülüs, celi-talik ve talik olmak üzere üç farklı yazı tipi görülmektedir. Katalog 1, 4 ve 8 üzerinde celi-sülüs, Katalog 6 ve 9 üzerinde celi-talik ve Katalog 3 üzerinde talik hat kullanılmıştır.

Mezar taşları üzerinde yer alan kitabelerde; Başlangıç İfadesi, Durum Bildirme, Tanrıdan İstek, İnsanlardan İstek, Meslek, Sülale Adları, Ölenin Ad1, Tarih gibi ifadeler yer almaktadır.

\section{SONUÇ}

Mezarlıklar ve hazirelerdeki tarihi mezar taşları eski Türk şehirlerinin bir bakıma "tapu senetleri” olmuşlardır ${ }^{30}$. Bu çalışma ile birlikte Keşan Hersekzade Ahmet Paşa Camii Haziresindeki mezar taşlarının bir araştırması yapılmış ve mezar taşları belgelenmiştir.

Keşan Hersekzâde Ahmet Paşa Camii Haziresi içerisinde, günümüze sağlam olarak ulaşabilmiş toplam 6 baş taşı, 5 ayak taşı ve ayrı olarak 1 adet

${ }^{28}$ F. Çavuş, age.,s. 69.

${ }^{29}$ M. Özer, agm.,s. 507-524.

30 Semavi Eyice, "Mezarlıklar ve Hazireler", Íslam Dünyasında Mezarlıklar ve Defin Gelenekleri- Cimetières Et Traditions Funéraires Dans Le Monde Islamique, Cilt: I, Ankara, 1996, s. 124. 
başlık yer almaktadır. Bu mezarlardan Katalog 1 sandık (lahit) mezar tipi, diğerleri toprak mezar tipindedir.

İncelenen mezar taşlarının 9 tanesi gövdesi dikdörtgen düşey kesimli formda olup, 1 tanesi silindirik formdadır. İncelemiş olduğumuz mezar taşları içerisinden, üzerinde tarih ibaresinin yer aldığı en eski tarihli örnek 1519 yılına, en geç tarihli örnek ise, 19. yüzyıla aittir.

Mezar taşlarında, yörede sık olarak bulunan değişik yapıdaki taşlar kullanılmış, işleme yöntemi olarak ise zemin oyma tekniği uygulanmıştır. Süsleme kompozisyonu olarak ise asma, Selvi, lale, yapraklı çiçeği, kıvrık dallar ve soyut yapraklı bitkisel karakterli motiflere yer verilmiştir.

Keşan Hersekzâde Ahmet Paşa Camii Haziresinde bulunan mezar taşları, genel olarak Edirne şehir merkezinde yer alan, diğer hazireler içerisindeki mezar taşları ile benzerlik göstermektedir.

\section{KAYNAKÇA}

Akıncı H., "Kara Taşlı Mezarlıkların Önemi ve Hersekzade Ahmet Paşa Camii Haziresinde Yer Alan Mezar Taşları", Hersekzade Ahmet Paşa Cami Sempozyum Bildirileri ve Etkinlikleri 15 Nisan 2011, Edirne, 2012, s. 78-96.

Arseven, C. E., "Baş Giyimi - Baş Giyeceği”, Sanat Ansiklopedisi, Cilt: I, 1983, s.182185.

Ayvazoğlu, B., Güller Kitabı, İstanbul, 1999.

Bacque, J.L. vd., "Tarihsel Kaynak Olarak Osmanlı Mezarlıkları: Uygulanan Yöntemler ve Bilgisayarda Yapılabilecek İşlemler”, Erdem, Ocak-1990, Cilt: 6, Say1: 16, 1992, s.197-214.

Baş E., Edirne Beylerbeyi Camii Haziresi'nde Bulunan Mezar Taşları, Edirne, Trakya Üniversitesi, Sosyal Bilimler Üniversitesi, Yayımlanmamış Yüksek Lisans Tezi, 2009, s. 553.

Çal, H.- Çal, Ö.A., Kastamonu Atabey Gazi Camisi ve Türbesi Hazirelerindeki Mezar Taşlarl, Kastamonu, 2008.

Çal, H., "Türklerde Mezar-Mezar Taşları", Aile Yazıları, Sayı:8, Ankara, 2015, 303305.

Çal, H. "İstanbul Eyüp'teki Erkek Mezar Taşlarında Başlıklar", Tarihi, Kültürü ve Sanatıyla Eyüp Sultan Sempozyumu III. Tebliğler, 28-30 Mayıs, İstanbul, 1999, s, 206-217.

Çavuş, F., Osmanlı Mezar Taşlarınin Strlarl, İstanbul, 2018.

Dere, Ö.F., Eyüp Sultan'da Taşa İşlenen Medeniyet, İstanbul, 2011.

Eyice, S., "Mezarlıklar ve Hazireler", İslam Dünyasinda Mezarlıklar ve Defin Gelenekleri - Cimetières Et Traditions Funéraires Dans Le Monde Islamique, Cilt: I, Ankara, 1996, s.123-134. 
İşli, N.H. "Edirne Mezarları ve Taşları", Edirne: Serhattaki Payitaht, İstanbul, 1998, s. 445-447.

Karademir, M., "Keşan'da Bir Osmanlı Hatırası: Hersekzade Ahmet Paşa Camii”, Hersekzade Ahmet Paşa Cami Sempozyum Bildirileri -ve Etkinlikler 15 Nisan 2011, Edirne, 2012, s. 67-76.

Kökrek, M., "Edirnekâri Şahideler”, Türk Dünyası Tarih Kültür Dergisi, 2015, s. 1821.

Kurtişoğlu, G., "Sadelikten Gösterişe Edirne Osmanlı Dönemi Mezar Taşları", Trakya Üniversitesi Edebiyat Fakültesi Dergisi, Cilt:8, Sayı:16, Edirne, s. 34.

Laqueur, H. P., Hüve'l- Baki, İstanbul'da Osmanlı Mezarlıkları ve Mezar Taşları, (Çev. Selahattin Dilidüzgün), İstanbul, 1997.

Ökçesiz, M., Kuşadası Adalızade Osmanlı Mezar Taşları, İstanbul, 2013.

Örnek, S. V., 100 Soruda İlkelerde Din, Büyü, Sanat, Efsane, İstanbul, 1988.

Özer, M., "Edirne'deki Osmanlı Dönemi Mezarlıkları-Hazireler, Mezar Taşları ve Türbeler", Konya Kitabı X (Rüçhan Arık - M. Oluş Arık'a Armağan), Konya, 2007, s. 507-524.

Pala, İ., Divan Şiiri Sözlüğü, İstanbul, 1999.

Sürün, M., "İstanbul Şeyh Vefa Camii Haziresi Mezar Taşları Tipolojisi Üstüne Bir Değerlendirme", Marmara Üniversitesi Türkiyat Araştırmaları Enstitüsü Türk Sanatı Anabilim Dalı Türk Sanatları Bilim Dalı Yayınlanmamış Yüksek Lisans Tezi, İstanbul, 2006. 